\title{
Introduction to the Handbook on Human Security, Borders and Migration
}

\author{
Natalia Ribas-Mateos and Timothy J. Dunn
}

We are intrigued about world borders, their history and their spatial representation. We are interested in rediscovering the importance of spatial structure shaping globalization, which has deeply challenged geographic borders that were once "fixed" historical divisions of sovereignty and citizenship. This is why we are attentive to the changing role of borders in the twenty-first century. We are interested in researching how border zones are made up of assemblages of capital, objects, people, information and different contradictory and violent policies.

We are also intrigued with the logistics and designs of global borders. Furthermore, we see border zones as blockades to mobility or the slow-down of the mobility of people. How do different types of cross-border mobility reflect classic personhood in light of the contemporary understanding of humanitarianism and compassion? We consider the concept of classic personhood understood as the status of human beings having individual and social human rights.

The present era is marked by expanding state restrictions to the cross-border mobility of certain types of international migrants, particularly refugees and low-income labor migrants. This especially manifests in the Mediterranean and US-Mexico border regions, sites of contact between developed and developing nations and the movement of people from the Global South to the Global North. It is also exemplified in many other different areas of the world. In turn, we are witnessing the expansion of manifold forms of migrant humanitarian assistance and solidarity across these contested border zones. This type of solidarity is connected to a progressive form of activism, using transparency and sharing information in different scales and territories. Thus, the challenge is to carefully piece together the different blurred pieces of given information through a long-term empirical and theoretical examination. This is displayed by most of the contributors to this handbook, ${ }^{1}$ who cumulatively cover a very diverse array of borders throughout the world.

Drawing on the concept of the "politics of compassion", the book begins with the premise that persistent violence in border areas needs further investigation. More specifically, individual chapters of this edited volume provide different analyses in case studies in a wide variety of border areas which vividly describe the lived experiences of people. By doing this, the chapters in this book raise important research and theoretical questions regarding contemporary forms of border violence (Jones 2016); they interrogate the political, geopolitical, social and anthropological processes in the contemporary global moment we live in. The chapters of the book map different aspects of structural violence in specific border zones, forms and practices which connect with labor exploitation, legal exclusion and a severe absence of human rights. However, they also consider the possible resistance to the proliferation of such violence, by taking into account remarkable efforts that communities and activists put forth to survive and challenge these oppressive arrangements. This volume highlights the dynamic, asymmetric relationship between the social structure of border enforcement and the human agency of migrants and activists. 


\section{Handbook on human security, borders and migration}

Given that the lack of human security is a principal cause of migration, we also contemplate how advocates and activists attempt to provide this to migrants. Human security is a framework that shifts the focus of security from nation-states to people. ${ }^{2}$ It consists of a broad array of characteristics rooted in human rights that impact the well-being of people everywhere, but especially those most vulnerable, and includes the following types: personal security, economic security, food security, health security, political security, environmental security, and community security (United Nations (UN) Human Security Unit 2009). Migrants are typically fleeing the lack of economic and personal security, conditions that are often exacerbated by financial, corporate, and coercive foreign policies of wealthy core nations (Graham and Poku 2000; Edwards and Ferstman 2010; Vietti and Scribner 2013; Purkayastha 2018). ${ }^{3}$ Further, the exclusionary border securitization policies of core nations have also increasingly undermined migrant human security, while doing little to boost the actual human security of receiving country populations. ${ }^{4}$ The security of one group cannot be built successfully on denying the security and humanity of others, which is implicitly recognized by migrant/gender activists and advocates.

Lastly, this handbook highlights key influential topics in the social sciences today: the structure-agency link, the human security ${ }^{5}$ and human rights nexus within global border conditions. The border site represents then the materialized contradiction between national sovereignty (the power of the nation-state) and the degrading of human rights of migrants. The state uses its hard-security arm to territorialize and protect its sovereignty, creating ripe conditions for violence and human rights abuses in border zones.

These themes are shown through a diversity of cases and topics outlining the plan of the book, which is divided into five sections: (I) The Iconic US-Mexico Border Region; (II) On the Way to the US; (III) Challenging Mediterranean Borders; (IV) Regions, Partitions, and Edges; and (V) Violence and Containment: Approaches to Youth and Gender. Each part presents an interesting array of case studies from the world, and that is the real innovation of the book; there is certainly no other work that challenges contemporary border conditions through research from a human security and politics of compassion perspective.

\section{STATE OF THE ART}

Since the beginning of the twenty-first century we have witnessed a proliferation of scholarly works which have sought to identify and interpret the relationship between socioeconomic and broader social problems in border regions, principally related to constructing different forms of new identities in different border regions of the world (Ribas-Mateos 2011). A range of parallel social processes - based in the movement of capital as well as people ${ }^{6}$ - are taking place at global borders in relation to mobility and the different cultures of humanitarianism in the twenty-first century. The border site not only represents the materialized contradiction between national sovereignty (the power of nation-state) and the degrading human rights of migrants (Dunn 2014), but also the clash between the humanitarian projects and neoliberal logics overpassing the state boundaries.

For this shared venture, in this handbook, we will focus largely (but not exclusively) on two paradigmatic cases, the borders of Mexico and the United States and different regions of the European Union (EU) and the Mediterranean. We also examine other world cases through 
involving the different regional cases (as there is a part on regional cases outside those main regions), as well as a final part focusing on specific approaches to youth and gender.

Most border regions feature militarized border enforcement as well as similar (un)humanitarian policies, directed at asylum seekers and irregular migration. ${ }^{7}$ The humanitarian/ unhumanitarian focus is considered from different angles. The state policies are generally increasingly inhumane. The humanitarianism is in principle provided by advocates and activists but also by the welfare state and by international institutions.

Nevertheless, more complex mobility occurs at these borders, including privileged (by class, race, and gender) and other differentiated and sorted types (e.g. by visa and commerce). The iconic US-Mexico border region and the contemporary transformations of the Mediterranean Sea as a region are key sites for the fraught relationship between global wealth and global poverty as well as coercive control of human mobility and humanitarian action. In the former region, Dunn contrasts the importance of immigration enforcement and its human rights problems $(2009,2014)$, which builds on previous works on border militarization (Dunn 1996, 2001). Human rights implications are here manifold, including continually high border-crossing deaths, widespread racial-ethnic profiling, denial of due process, and the use of increasingly widespread punitive detention measures. Furthermore, it is now well recognized that the US model of border militarization has been exported to many other border zones (Miller 2019).

According to Heyman and Ribas-Mateos (2019), three key kinds of relationship are involved in such a border regional context: (i) Militarized barriers (combined natural and human-made) that prevent the entry of peasant-workers and working classes from the Global South. This includes both uninspected entry of unauthorized workers and asylum-seeker attempts. But mixed with official rejection is humanitarianism of various kinds, both state management of migrant bodies to avoid bad political publicity, as well as resistant humanitarianism from below by activists and organizations. (ii) A permeable membrane (a system of entry inspections) that allows a range of other people to enter the space of relative wealth, including elites, tourists and shoppers, non-immigrant temporary laborers, some family members, etc., as well as massive flows of commercial goods. These are crucial to global alliances of economic, political, and intellectual elites. (iii) However, not all labor crosses the border; indeed most does not. Border enforcement reinforces a global division of labor which often places low wage production sites in the Global South and prosperous consumption sites mostly in the North (ibid.)

The challenge for empirical research in the Mediterranean, as well as for other regions in the world, is that they are often contrasted with more paradigmatic ones, such as the US-Mexico case (Ribas-Mateos 2011, 2015). Therefore, one of the main problems of "the universality of the US-Mexico border" is that it creates a "new ethnocentrism" implying that other borders will resemble it. Of course, the history and the culture are not the same in such distant regions, nor are the problems surrounding cross-border dialogue (e.g. US-Mexico, Southern Europe with the Maghreb). Differences are also constructed in welfare regimes, migration regimes, types of circulation, type of closure, and so forth. We argue that the Mediterranean setting is key for observing cross-border mobility historically and in the present moment. Here, borders are intertwined with mobility filters that differentiate people according to social categories in a place that is today one of the most militarized and heavily patrolled areas in the world, and, in the last decade, the most lethal border region in the world. In addition, this Mediterranean setting - beset by conditions of socioeconomic crisis, weak social policies, restricted borders, 
and multiple forms of mobility - exceeds rigid, established area studies and spills over into examining the interrelations between the EU, Southern Europe, North Africa, the Arab/Berber North Africa, the Middle East (also including Iran, Turkey, and Kurdistan), the Balkans, etc. In contrast, US-Mexico border studies are built on a more unified view of North and Latin America, while Mediterranean migration studies would be more fragmented and diverse. Over the last ten years the production of research and studies on border conflicts in the Mediterranean has increased dramatically - (over-production of publications in that sense), especially after the biggest tragic shipwrecks in the island of Lampedusa in 2013.

Indeed, there are many European borders related to mobility restriction that are not located on the classical sites of geopolitical conflict of the 1990s, such as the Strait of Gibraltar or the Otranto Channel. Today, the list of sites reflects more the tensions of migration across boundaries of wealth and poverty. We can illustrate it as: the Strait of Gibraltar and the Canary Islands, Lesbos, Greece; Malta; Lampedusa island, Italy (especially after the 2013 tragedy); the Sicilian Channel and other borders of Southern Italy (the route through Libya/ Tunisia); Calais-Dover (with a Schengen border); the borders of the East, etc. Even if highly exposed in the media and more well researched in recent years (compared to the 1990s), the Mediterranean model needs to be understood in a long durée perspective of policies in the changing construction of "Fortress Europe." In the Mediterranean (also including here the Middle East), border transformation is accompanied by severe social inequalities expressed in different ways: increasing limitations placed on the mobility of refugees ${ }^{8}$ and migrants, yet decreasing limitations on the cross-border flow of goods; the proliferation of refugee encampments and settlements (formal and informal); human vulnerability and rights violations; and expanded border securitization. How do we understand such changes in the formation and proliferation of the world's borders - from the notion of the strict classic border defined by geopolitical lines to the complex meaning of intensified conflict and contention of migration in the era of globalization?

These more recent trends in the Mediterranean have long been present in the US-Mexico border. They have played out in especially stark fashion in major cities and border sites, most notably in Southern Europe and also the US-Mexico border, especially during the Trump era. In these sites the contradictions are stronger between ordinary cross-border mobility for most people versus the reinforcement of border closures for other specific people on the move, particularly migrants and refugees, and an acute deterioration in their human rights and human security. It is here that we locate the revival of ancient political questions regarding the "rights to have rights" and the role of human rights defenders in border zones.

Undeniably, camps of all sorts are becoming a central step in refugees' journeys, as they structure their mobility and drastically limit their access to human and social rights (see the concept of "encampment of the world" in Agier 2014; Lagarde 2016). A case in point is the situation of the "migrants trapped in Libya" where UN institutions, European actors, national actors, multiple militias, non-governmental organizations (NGOs), hegemonic media, and independent media all play an important role in creating and revealing a complex situation of multiple forms and sources of violence ${ }^{9}$ - particularly sexual and gender-based violence and other extreme violence ${ }^{10}$ - and eliciting a politics of compassion and mobility in the Mediterranean (forthcoming, Ribas-Mateos 2021).

While this regional comparative border research has been a breakthrough in the study of migration in relation to their effects on spatial and social parameters, we believe that new emerging issues require a thorough analysis in order to better understand the contemporary 
reality of international borders. Issues such as the securitization of borders, humanitarian intervention in border areas, and the analysis of the conditions of violence exercised on people in transit (taking a careful gender perspective on such mobilities) reveal a changing, urgent reality that needs to be studied in detail by academics, border activists and policy-makers. In order to respond to this new reality centered on the clash between border security and humanitarian policies, the chapters in this handbook converge in these types of responses:

(i) They review the existing forms of conditions of vulnerability to violence in border areas and the policies of compassion that are put in place in response, beyond the classic paradigms of the "victim/survivor" (for example, sea victims in the Mediterranean). Such policies can be understood as humanitarian contradictions in the studies of violence and protection. ${ }^{11}$ Do vulnerability and agency engender new notions of humanitarianism within global networks? How do migrants and refugees shape the complex understanding of borders in different parts of the world?

(ii) They emphasize the emergence of new forms of transnational solidarity within a framework of feminist solidarity (for example, anti-feminicidios networks in El Paso Juárez on the US-Mexico border). Such aims are inserted in the interest of the politics of compassion in both regions and beyond. We understand the politics of compassion as the moral-political dimension of humanitarianism set in a complex social process that is contradictory and constrained by unequal and authoritarian political contexts (Ticktin 2012).

\subsection{The Politics of Compassion}

In the twenty-first century, humanitarian responses to challenging crisis (such as Covid) are emergent preoccupations for most societies which are still using humanitarian tools conceptualized during the mid-twentieth century. In practice, humanitarian aid aims to save lives and alleviate suffering, but it is normally less concerned with upholding human dignity. In other words, humanitarian aid, through assistance and the growing spectrum of protection activities, aims primarily to tackle the effects on human beings of extraordinary circumstances as in contemporary border crossing. Through our view a context in which to first locate how to think such politics of compassion in border areas would especially find its roots in the concepts of human suffering, politicized pity (as referred to by Arendt 1973 ${ }^{12}$ ), and the concept of compassion itself. ${ }^{13}$

Much of the core of such debates is present today when solving the contradictions between those who help and those who are helped, which displays the main contradictions of humanitarism in social environment relationships. According to Fassin (2012b), the emphasis is between solidarity and structural inequality between the helper and the helped, between the compassion fatigue of the helper and the tension of the asymmetry of the helped. ${ }^{14}$ Therefore, this opens up an unsolved paradox emerging in this handbook as a contradiction in border politics: in other words, the transformation of the political on the moral terms (for example, in a compassion form). Or as Fassin (2007) recalls - the transformation of the political milieu into a moral, medical, and psychological profile of the victim. Put differently, the clash is placed between national sovereignty (political) and the human rights and human security of migrants (moral). 


\section{Handbook on human security, borders and migration}

In general, the wide gap between the protection migrants formally enjoy under international law, and even under national laws, versus the actual experiences of individuals, reveals a severe absence of human rights, as states tend to distance themselves from state-based obligations towards migrants and refugees, not only in wealthy countries but also in other regions like the Middle East. In that region, exile, statelessness, ${ }^{15}$ and refugee crisis have been the result of the state-building process.

In this glaring contradiction, we also see many of the main issues related to global borders: securitization, the constant search for re-routing, the importance of irregular migration, entangled forms of legal and institutional racism, complex gender issues in mobility trends, the increasing autonomous migration of minors, different forms of human trafficking, globally networked surveillance, etc. At these border sites we also witness humanitarian aid - as well as the varying other reactions of civil society in border regions.

Together with the moral-political dimension added earlier by Ticktin, we understand the politics of compassion as the moral-political manifestation of humanitarianism present among the different social actors in a particular global border. In studying this phenomenon, we draw, in part, on the work of Luc Boltanski (in the "distant suffering," 1999) and his framework of "pragmatique." This framework takes an inductive approach of observing actors in order to discern the principles of their actions and contradictions - and by extension in our handbook, observing multiple actors dealing with borderlanders and border communities in a wide range of border and migration contexts.

We can review the politics of compassion here at least in three clarifying examples, the first, located in the US-Mexico border, the second located in Morocco, and the third located in the Central Mediterranean migrant route. They are key examples to elaborate the politics of compassion; however, we will cover other Mediterranean cases in a more general way.

Generally speaking, we could take as illustrations many examples regarding such contradicting policies. First, when considering migration to the US, Uehling (2008) addresses the politics of compassion on the case of the 100,000 children apprehended in the US as unaccompanied minors, plus the number of children who escape detention measures. In such policies of compassion, Uehling examines the robust national and ethnic hierarchies which are used in the policies and practices of children's detention by US administrations. These hierarchies are manifest not only in the likelihood that a child will be sent back to a country of origin (rather than reunited with family in the US), but also in the type of attention that a child receives from the time of their apprehension until their release. The image used here is the classic "the hand that rocks the cradle" used as a protection image for migrant children in the US.

Ultimately, the politics of compassion have created an uneven terrain of protection for children. Such inconsistencies involve, on one side, protection to the innocent, and, on the other, discrimination against children by country of origin, creating a tension in the framework guiding care ${ }^{16}$ Children, therefore, throw into bold relief two contradictory impulses in immigration policy and discourse: an impulse to protect them as vulnerable persons (generating politics of compassion), and an impulse to "protect" and barricade borders. Since 2018 the Trump administration has opted strongly for a punitive child migrant detention policy marked by extreme overcrowding and unsafe conditions as well as family separation, intentionally constructed to attempt to deter future migration.

A second example is Jiménez's (2019) illustration of how the politics of compassion are shown in the processes of European externalization of borders in the Western Mediterranean region. Through politics of migrant control, a victimization process is developed by counting, 
researching, and assisting them. According to her view, these practices of humanitarianism position the migrants as passive and "compassionated" objects, while mediators such as cooperation workers, doctors, translators, etc. are the active subjects and recipients of funds dedicated to migration policies. However, counting, researching, and assisting migrants in border areas are much less severe forms of victimization than the strict, punitive border enforcement by nation-states. However, one might argue that paternalism is preferable to direct repression.

The third example is the theoretical-empirical work of Poguisch (2018) in the Central Mediterranean route. She analyzes such politics especially after 2013 connected to the Mare Nostrum Operation, where "saving lives was put on the European Agenda," and later on with treaties between Italy and Libya. These treaties tried to synthesize humanitarian rhetoric with governmental policies of migration management. However, she points out the ambiguity of such humanizing policies was expressed in multiple ways - for example, the contradiction between border control and humanitarian rescue prevents many migrants from reaching Europe.

\subsection{The Changing Twenty-First-Century Borders}

Borders usually contain a strong visual component, most dramatically symbolized in the idea of a wall. However, even in these physical expressions of border-as-restriction or closure, border spaces are inherently partial, selective, and opportunistic in their presentation as well as in the interests they serve. For instance, they simultaneously exclude and facilitate the mobility of other subjects and objects. Recognizing the multifaceted, contradictory nature of borders challenges conventional thinking and practices about problems that are non-linear, diffused, and simultaneous.

Reflecting this perspective, we draw upon a wide range of disciplines, methodologies, and concepts from ethnographic vocabularies to view the border as the embodiment of mobility and globalization. Therefore, based on the evidence of our collective experiences in the field (of all contributors) as well as existing research, we argue that the border is a key place of contemporary global construction, as globalization questions border capacity; borders are a clear expression of empirical global contradictions, a key empirical research site, and for such reasons it is our main focus of analysis.

Correspondingly, there are different types of academic literature on borders. For example, there is great deal from the US devoted to borders as metaphors for hybridization, creolization, multiculturalism and post-colonialism. Our approach is different, as we visualize borders as empirical realities that reflect intricate global socioeconomic processes, wherein borders act as frames (contexts) instead of objects (they are socially embedded relations), from which we can observe border filters, processes of space deterritorialization, ${ }^{17}$ and processes of industrial outsourcing in the same manner as Sassen (2014) has analyzed.

About what kind of borders are we talking about? As mentioned earlier, cartography has offered fertile ground upon which to stress border changes throughout history (frontier, boundary, border, etc.). But this handbook is focused on a more complex understanding of such concepts, with a special emphasis on the dynamic, interactive, multilayered nature of border relations entangled with different mobilities which open up important questions on human rights and vulnerability.

In several of the past works previously carried out by the contributors, they shed light on what "the vulnerability of human rights" means today, by researching the experiences of vul- 
nerable populations in border regions. They are impacted by the relocation of the industry and services industry (as care work) (see Oso and Ribas-Mateos 2013, among an extensive already published literature), and its effect on the labor market, gender and class inequality, extreme violence, as well as forms of resistance against human rights abuses that occur especially in diverse border areas. Thus, the contributors also address the issues of solidarity, humanitarianism, and border activism as a global action in these specific sites as key ways of analyzing contemporary violence.

Additionally, we refer here to a theme very present in border literature of the "fabrication of corpses," which in the book covers at least four different contributions. This can be clearly associated with "the manufacture of corpses" that Arendt (1973) pointed out as the characteristic of a totalitarian regime, wherein one can analyze the limits of human experience. She referred to the fabrication of corpses or the factories of destruction that the totalitarianism of the holocaust developed. They are zones of oblivion, where rights are annihilated and forgotten, and as Jacques Rancière (2003) adds, where not even humanitarianism is enough. Many independent journalists and many activists are working on these issues located in the Central Mediterranean route where such parallelism can be made, even using the concept of "genocide" (forthcoming, Ribas-Mateos 2021). Others might think that such parallelism can be far too extreme. Regardless, it is clear that powerful organizations are undermining human rights and actively neglecting the protection and well-being of the "truly disadvantaged," highly vulnerable migrants and other outsiders in a process of "social triage"18 (Sjoberg 1999: 54-55, see also Sjoberg et al. 2001). This author gives us here a setting to understand how powerful bureaucracies tend to harm disadvantaged groups and are rarely held accountable.

\section{OUR PURPOSE}

With these theoretical approaches emphasized, our general purpose is to analyze the changes and the challenges of the impacts of globalization on borders, without ever forgetting the past (the history, see Sahlins 1990)), the present moment and the future challenge, and without forgetting the spatial fix as also going beyond such spatial mapping (externalization of borders, internal borders, deterritorialization). The contributors offer a solid theoretical framework (based on long-term research practices), and address public policy and institutions (governments, independent associations, universities), in the US-Mexico region, the Mediterranean region as well in other areas of the world: Latin America, Africa, Asia.

The general themes more fully specified are:

First, to reveal the contradictions between border security and humanitarianism, paying special attention to discourses of compassion, which offer a more humane and egalitarian response to migration in contrast to more common racially and ethnically biased policies. And to analyze the practices and policies which are structurally connected to such discourses of compassion.

Second, to analyze the dynamics of solidarity in border regions that respond to the challenges of securitization and the different forms of violence suffered by migrants in transit across borders, and violence to borderlanders, etc.

Those themes are connected with several more specific focal points of analysis in this handbook: 
(a) Analysis of the concepts of violence, compassion, and mobility in different humanitarian border environments. Through these three ideas, we will review the logics of border governance in Morocco (Jiménez's chapter), applicable throughout the Southern Mediterranean and other borders in the world. We will analyze the structural and daily violence faced by migrants in their transit towards Europe (outsourcing processes and the so-called "war against migrants") within the framework of a new European rhetoric of human rights as a part of border enforcement policies. In this we underline the reconstruction of human testimony - for example, in the cases of extreme violence - by using very careful interviews with witnesses.

(b) Analysis of the transit of recently arrived Latin American migrants in the EI Paso-Texas area and the reproduction of border restrictions, as well as the forms of solidarity to people in transit. See, for example, the works of Heyman or Bejarano and Hernández Sánchez in the handbook. On the US-Mexico border, the traditional migration of Mexican laborers has declined drastically, now largely replaced by Central American families and unaccompanied minors, many of them asylum seekers. Using the concepts of violence, compassion, and mobility in a multiplicity of border spaces, we can see a national political response of incitement to moral panic towards asylum seekers, including coercive "prevention policies" (before the physical blockade at the border) and the punitive treatment of those who do not manage to enter (family detention, family separation). This harsh process is countered by a response of growing compassion and care from the border population and compassion towards migrants in transit.

(c) Analysis of the forms of transnational feminist solidarity as a form of solidarity in humanitarian work. Dramatic changes in immigration, migration and refugee policies, as well as the exaggerated security measures such as "building a wall," have resulted in new patterns of forced diaspora from Central America, various parts of Latin America and the Caribbean (including Haiti), Africa, and migrants from untypical countries arriving at the US-Mexico border. Bejarano and Hernández Sánchez (in this book) explore these migration patterns towards the US-Mexico border from the feminist perspective by emphasizing an analysis of this new mobility and the intersection with gender, sexuality race, ethnicity, and other cultural images.

(d) Analyzing how a gender perspective interrogates cross-border geographies in different humanitarian border settings, particularly under circumstances marked by the conditions of extreme border violence. The project also investigates complex mobility and geographies of resistance from a cross-border feminist perspective.

The handbook coverage also addresses: population displacement, migration policies, the responsibility to protect the vulnerable, the analysis of the culture of violence, the transnational and local dynamics of violence, as well as new social practices around border phenomena. Moreover, this handbook also aims to rethink borders from a critical position, shed light on the dynamics of solidarity in response to violence, and analyze the different discourses built upon the politics of compassion. 


\section{WAYS OF APPROACHING BORDER FIELDWORK}

Many case studies shown in the book are observed from the forces of economic neoliberalism placed in borders. But, of course, not all results are the same. Each case has roots in its own history; the contextual history of the site also shapes the neoliberal logic. Therefore each case, even with rampant communalities, displays a diversity of rhythms, dynamics, and variety of social practices.

Despite the increasing number of case studies on different borders across the world and the deepening of theoretical and conceptual thoughts on borders and bordering in global regions, there is a significant lack of systematic and comparative reflections on the methodological foundations and consequences of border studies, going beyond the limitations of border scholars' research circumstances. In our understanding, methodologies link theoretical and empirical research accounts as they gather the relationship of the heuristic use of theories, epistemological perspectives, choice of different research methods, reflections on the research process and the role of the researcher, and the use of different types of data and forms of interpretation. We will focus below in a specific methodological set:

(a) The general methodology is based upon the elaboration of the research that most of the participating researchers have been working on for at least the last ten years. We base our work in a long durée involvement.

(b) The theoretical framework in which many cases are inserted are in a way a continuation of the collective works carried out in the past (see, for example: the 2011 book (in Spanish) The Rio Bravo Mediterráneo. Border regions in the era of globalization, by Ribas-Mateos). The theoretical-empirical viability of this work is justified by the internal coherence of the joint efforts conducted by researchers over the last ten years as well as incorporating new young authors and researchers from other parts of the world into the collective project. Since that publication, authors have added the complexity of economic global processes, forms of resistance to anti-Trump cultural assumptions, and the emergence of transborder activist feminism.

(c) Action research methods in social sciences are applied, within a human rights perspective, particularly in the study of violation and support of human rights in border areas. Such action research also includes: the direct consequences towards the population in contexts of armed conflict or serious social conflict; forced displacement of the population and economic immigration; and criminalization of the resistance.

(d) Grounded theory: We use comparative methods and emergent theorizing, based upon grounded theory as a powerful tool for linking research-to-practice across disciplines. This can be particularly effective for practitioner-driven border issues, regarding:

- Conflicts and human rights, for example, through the analysis of the involvement of the actors that operate in situations of armed conflict or serious social conflict and their impacts on people, human rights and the general protection of universal rights.

- The identification of best practices and lessons in border areas through actions directed by different border networks that respond to different aspects of border violence.

Within this grounded theory more inductive approach, various texts do inform us on the effects of capitalism, the concentration of settlement around border sites of global production and exchange, which is an important traditional focus of border ethnography (Heyman and 
Ribas-Mateos 2019). In many chapters there is a background of border ethnography: they include border narratives, identifications and political movements that speak to resistance and reinforcement. Therefore, the book also develops a critical stance regarding border theory, which has become very important in the last decades in several academic circles, not only in the United States but also in Latin America and in the Mediterranean region. Most ethnographic inquires of the book are also theoretically laden. Such border perspectives are also very related to the new anthropology, which is often mobile and multi-sited as well as implying complex forms of activism. The new racism that arises in multicultural late global capitalism splits the other into halves in order to celebrate one of those halves while demonizing the other $[\ldots]$. But other aspects are framed as "fundamentalism" and rejected (Mexican machismo, fatalism, violence, etc.). This is precisely the "trick" global capitalism performs to guarantee its world expansion.

As Vila $(2000,2003)$ gives us some notes on how to conduct ethnographic work in the US-Mexico border, in the Mediterranean region the asymmetries are put in a different context. Through his work Le proche et le lointain, Rachik (2012) shows us the axis which can be underlined in a ethnographic border situation. Through a cognitive axis - based on theory construction - with an endo-exo (inside-outside) articulation which can cover all the distinct categories of the fieldwork in Moroccan colonial ethnography, the "beldi" and the "roumi", the foreigner and the outsider. However, he underlines how important it is to overcome the binaries of the fieldwork encounter: the civilized/the savage, the Christian/the Muslim, the colonizer/the colonized. He insists in taking into account the subjective, relational dynamic of the fieldwork.

\section{THE HANDBOOK CHALLENGES}

This handbook is innovative in its topic and framing, range, and combination of issues addressed, multi-continent research collaboration, and multiple research methodology employed. We detail below the most innovative aspects which the different authors deliver in this common production.

\subsection{A New Research Field?}

Until recently, in the countries at the center of capitalism, labor supply and demand were more balanced; there was also, more or less, a "freedom of relative circulation of labor" (or pushed to underground/undocumented migration in some regions, like the US-Mexico case). Currently, we are in the presence of a strong "mismatch," or imbalance in the labor market demand-supply, compared, for example, with the high-labor demanding situation in Western Europe in the 1970s when migration was openly needed and requested. In addition to this dilemma of an over-supply of labor, there are a number of other problems: the coarsening of the social climate between communities, the use of xenophobia as a political argument, a highly securitized model of border area management (especially after September 11), and the general impact of immigration restrictionist policies (in the US, Europe, and transit countries).

Within this current background, Heyman (in this book) shows how the border between Mexico and the US is one of the places, par excellence, where the processes of "globalization" are concentrated and expressed openly. On one hand, some 13 million people live within 
a region of what can be perceived as a successful example of economic, social, and cultural integration of a binational society. On the other, however, this same border area is also the site of rigorous instruments of control of migratory flows from Mexico and other Latin American countries, based on a security model stressing "national sovereignty." This security policy has several perverse effects, such as the risks, often fatal, to which migrants are exposed, and the reinforcement of criminal groups that organize clandestine passage to the US.

The main contribution of the research in this handbook is to demonstrate the contemporary importance of mobility - of the mobility of people both inside and outside the two selected regions as the contemporary understanding of humanitarianism and compassion in the design of global borders. The Euro-Mediterranean group, on the one hand, and the AmericanMexican border zone, on the other, are configured as regional cases, and, in each of them, we can observe similar phenomena that are often described in diffuse and general ways, such as border restrictions in mobility filters, proliferation of the maquila ${ }^{19}$ export-assembly industry, the existences of a binational community, and humanitarian action.

Nevertheless, the originality of the book goes beyond these two selected border regions and beyond such issues as shown in Part IV, Regions, Partitions, and Edges, and Part V, Violence and Containment: Approaches to Youth and Gender. These include borders and violence in Burundi, the migration crisis of the Cameroon-Central African Republic border, governance of the vast Amazonian borders in Brazil, Brexit and the Irish border, the civilian blockade in the Crimea Ukraine-Russia border, the agency of West African women en route to Europe, Afghan children migrants in Iran, Moroccan children in Europe, racial profiling on the USCanadian border, and the smuggling regimes on the Gaza-Egyptian border.

\subsection{An Innovative Analysis of Border Filters}

According to Heyman (2011), an important quality of contemporary borders is that they classify or filter the mobility of different types of people and goods, based on a complex set of social, cultural, and economic inequalities.

Mobility has always been important in cross-border relationships and is even more crucial in the present era of the "compression of time and space" (as the interpretation of globalization implies). However, borders have increasingly broad roles in the control of people and goods. An example given by both Dunn and Heyman (in this book) is the patrolling of the 3,200 kilometers of land border between the US and Mexico by about 20,000 officers, hundreds of helicopters and fixed-wing aircraft, sophisticated cameras and motion detectors, hundreds of kilometers of wall, and so on. They make the crossing dangerous, but they do not deter it or stop it. Mobility control at legal entry points is also extensive and complicated, both from its conceptual form and from its practical application. Another current way of labeling this phenomenon theoretically, according to Adey (2004), is "sorting," or the "classification and separation" of different flows or groups of people.

While asylum seekers and unauthorized migrants receive the most attention from media, activists, and scholars, it is important to examine borders in terms of unequal mobility that includes millions of legal entries (see Heyman and Ribas-Mateos 2019). A diverse and complex range of people pass through the Mediterranean and US-Mexico borders, making a complete account unrealistic here, but there is a scattering of ethnographies of privileged crossers and the kinds of visas they hold (managers, shoppers, students, legal border commuting laborers, etc.), while others have looked at the differential inspections process by state 
officers at borders that sort out such crossers. More needs to be done, but we are beginning to understand borders as differentiating filters linking and managing stratified components of the world system. For this task, we need an ethnography of privilege and normalization as well as the reduction to "bare life" and risks in crossing, and humanitarian action at borders (see Heyman and Ribas-Mateos 2019). Ethnography then seeks to make connections between close-ups and extreme long shots. This ethnographic look allows different scalar views, thus allowing us how to see the way the macro situation connects with cases of local human rights violations, which connects together border political conditions with individual cases.

\subsection{Humanitarian Challenges to Borders}

Borders attract a variety of activists both from outside and within the border region. Activists include people broadly supportive of state enforcement, including those who play-act enforcement at borders (such as militia groups), and also pro-immigrant activists who provide humanitarian aid and advocate for migrants and asylum seekers. In the last decade much important work has been done on activism in the Mediterranean, especially since 2015, and particularly regarding displacement and camps, research on the forms of mobility and violence in border areas, and also regarding the politics of compassion. This work highlights the contradictions inherent between border security and humanitarian policies as well as the politics of compassion, moving beyond the classic paradigms of victimhood, ${ }^{20}$ which mostly refer to women and children.

Many authors have considered this humanitarian work during their different fieldwork projects. One classic example in the Middle East is the humanitarian pictures that politically position the concepts of "refugee" and "camp" as moral indictments of the states and agencies that impact refugees' lives (see the case of the Bekaa in Lebanon, Ribas-Mateos, ongoing research, forthcoming 2021). In the past and continuing case of the Palestinian camps, the idea of not settling into new countries has been seen as a form of agency, with the refugees focused instead on their return and economic survival. They were normally seen as revolutionaries rather than recipients of international aid or subjects of humanitarian crises (Marron 2016). However, from the perspective of the NGOs in the Mediterranean today there is a new form of humanitarism that is both rational and emotional, containing a fraternal spirit and a concern for the situation of other human beings, by expressing compassion and solidarity. This has arisen along with the new displacement of millions of additional persons in a brief time, stemming from multiple conflicts - many of which are tied to disastrous foreign policy and coercive interventions in the Middle East and North Africa by the US and major European powers. This highlights how humanitarianism is a response that is embedded in politics, as seen in the moral need to save lives. ${ }^{21}$ In this respect, there is a need to make clear that the receiving countries do play a major role in creating or worsening the conditions that many refugees are fleeing. They are the product, in part, of failed foreign policies and armed interventions.

This failure is very clear in the Mediterranean. The Mediterranean setting is constructed by a scenario which includes: socioeconomic changes in Southern European countries, mobility changes impacted by the Arab Spring, shipwreck events in the Mediterranean, EU emergency policies, proliferation of push backs, etc. They have all pushed an externalization of borders towards the South, towards Sub-Saharan Africa, especially from 2011 - the time of the Arab Spring - to 2015, and from 2015 until now, creating a crisis of border externalization and paired with a new phase of turbulence at the maritime frontier. In the aftermath of a major 
shipwreck involving a migrant boat and the loss of many lives on the Central Mediterranean route (April 2015), the Council of the EU launched "Operation Sophia," which was mandated to undertake systematic efforts to identify, capture, and dispose of vessels as well as enabling assets used or suspected of being used by migrant smugglers or traffickers - as a part of wider EU efforts to block south-north migration. Its justification is to disrupt the business model of human smuggling and trafficking networks in the Southern Central Mediterranean and prevent the further loss of life at sea.

One key aspect of these complex policies of compassion is the case of the re-imposed border externalization in Libya and closing off of the Central Mediterranean route by driving rescue NGOs out of the area and by expanding Libyan coast guard interceptions under EU coordination, and refoulement/migrant return southward. These EU policies are implemented mainly via Italy, to stem migration across the Central Mediterranean deployed as a strategy of delegitimizing and criminalizing migrant rescue operations by NGOs.

In the case of the "migrants trapped in Libya" (forthcoming, Ribas-Mateos 2021), the methodology involves a focus on human rights violations and defenses and a gender perspective. The work has particularly focused on the conditions of gender vulnerability and extreme violence. The general background is the articulation of the triangle: spaces of violence, politics of border compassion and mobilities.

\subsection{Emerging Forms of Resistance}

According to Bejarano and Hernández Sánchez (in this book) through necessity, vulnerable communities embark on strategies of resistance and challenge the blockades of the nation-state through the border regions. One can also add the use of the concept of "morality of risk," where norms of reciprocity and moral duties strengthen community networks despite the individual risk present at the border. Consequently, offering food, transportation, or lodging for migrants in the border regions are forms of defiance and resistance on the US-Mexico border.

On the other hand, this handbook is also novel in making scientific knowledge on these volatile topics available to society. The current reality - with the increase in hostility towards migrant populations, the increase of Islamophobia in Europe, or the closing of borders and heightening conditions of vulnerability to violence - highlights the need to provide society with new tools for analyzing the migratory reality and borders, which move away from misinformed rhetoric and discourse common in politics.

\section{STRUCTURE OF THE BOOK}

\subsection{Part I: The Iconic US-Mexico Border Region}

The first part starts with the base of the book, the iconic US-Mexico border region. Dunn provides an overview of the history and conceptualization of militarization in US border enforcement efforts along the US-Mexico border since 2000, focusing primarily on immigration enforcement, and some attention to the human rights problems accompanying this. His main finding is that contemporary militarization has increased through greater presence of military troops, military equipment, and a much expanded para-military Border Patrol force. The human rights implications are manifold, including continually high border-crossing 
deaths, widespread racial-ethnic profiling, denial of due process, and the use of increasingly widespread punitive detention measures. This constitutes an expanding, coercive form of organizational power directed against subordinate and vulnerable groups. Ultimately, for Dunn, human rights should retain a primary position, for although they are admittedly imperfect, they provide a more universal moral framework that is much less subject to the whims and destructive machinations of nation-states (and corporations) than are national laws (and corporate policies) and are more adaptable to diverse human agents and their struggles for dignity.

Heyman presents a very ambitious tour de force of a chapter on a complex multiplicity of violence, direct and structural, faced by migrants and residents also in the case of Mexicans. This chapter seems to be shaped by the reality of the wide range of violence (direct and indirect) trauma - after the horror and suffering that the region and many people have faced. This is a violent border, one of many in the world, with open violence from Mexico and hidden violence from the US. By violence he implies: both direct physical violence, including mental health and so-called structural violence. The border is here also an import symbol in enacting xenophobia, and the most violence engendering processes are enacted in this region. In El Paso, along with the Lower Rio Grande Valley, the border as field of contention between state agencies (US and Mexican) and voluntary humanitarians, another important domain of violence and suffering continues in the same space: the repressive drug war and small arms trade into Mexico. Homicides, disappearances, kidnappings, extortion, and physical and sexual assault are directed at Mexican-side border populations and migrants at extraordinary levels. While the logic of violence largely spares settled populations in the United States (though migrants in passage remain vulnerable), the total field of social life in the region is extensively subject to violence and victimization. The migration debates are well-publicized but the worlds of violence at the border are largely unremarked and normalized.

Bejarano and Hernández Sánchez examine the practice of migrants creating a "tent city within a city," one tent at a time, or one shelter at a time, transforming the urban scapes, political economy, and social relations of the border metropolis of Ciudad Juárez, Chihuahua, Mexico, as a phenomenon of being both displaced and disposable interlocks with ideologies of racism, classism, nativism, and sexism, formed in an intersectional vulnerability. They explore the tent city/settlement phenomenon via the interconnecting concepts of displacement, disposability, debordering, and re-bordering (within the modes of survival of different border populations, with reference to a "Border Tuner" project, which allowed people across borders to literally hear each other's heartbeats and to speak to one another without limits).

They describe tent cities as a system of symbolic basurization where both the US and Mexico profit ideologically from the construction of disposable people. For that they use ethnographic work on a tent city, through a system of border dialogues in order to do justice to our representations. They focus on the ethnography of displacement, analyzed as a previous experience of dispossession, as well as oppressive mechanism while appropriated as resistance. They view how tent city/ies, as small settlements appeared and disappeared suddenly. Thus, the contrast of human mobility of Central American migrants as forced migration clashes with a city facing at least three decades of violence.

Solís analyzes the different ways of crossing the border and its effects on bordering processes between Mexico and the US. She considers the Trump era as strengthening previous restrictive border policies within a network territory characterized by circularity, virtuality, instability, and conflict operating under a global context, which is not about the end of the 
states but the dispute over hegemonic power, where the nation-state becomes a strategic actor with new functions. Globalization entails then the "disassembly" of the nation-states in territory, authority, and rights, always within a capitalist logic that privileges capital.

Solis' chapter's main idea is that contemporary multi-territoriality is recreated by different populations in this context, generating a heterogeneous and complex landscape that allows the border to be thought of as a mobile and flexible device, which is built on territorial violence but also by resistance and by confluence. There are many types of border-crossing practices and experiences along the US-Mexico border, especially among residents in the region, which illustrate the complex nature of a border as both a point of contact and exchange as well as a barrier and exclusion. Further, these varied practices and experiences lead to a wide range of subjective understandings and views of the border among the diverse types of crossers and residents. This heterogeneity of border-crossing practices and subjectivities is very important to consider and is a good counter to both the common political view of the border as a security problem and crossers as threats as well as to the typical economic view of the border as a zone of international trade and commercial exchange. Much of the public and many policy-makers outside the region fail to keep in mind this vast volume of many different types of crossers and crossings (the overwhelming majority of which are legal), but instead see them as some sort of threat through a lens of illegality.

\subsection{Part II: On the Way to the US}

Expulsions on the way to the US originate in soaring income inequality and unemployment, expanding populations of the displaced and imprisoned, and accelerating destruction of land and water bodies. Sassen recalls how today's socioeconomic and environmental dislocations cannot be fully understood in the usual terms of poverty and injustice. Different examples in the US-Mexico-Central American region connections illuminate the systemic logic of these expulsions. The sophisticated knowledge that created today's financial "instruments" is paralleled by the engineering expertise that enables exploitation of the environment, and by the legal expertise that allows the world's have-nations to acquire vast stretches of territory from the have-nots. Expulsions lays bare the extent to which the sheer complexity of the global economy makes it hard to trace lines of responsibility for the displacements, evictions, and eradications it produces - and equally hard for those who benefit from the system to feel responsible for its depredations.

Camps-Febrer and Carter provide us with many important concepts and theoretical insights focused on the privatization of security and the state's receding monopoly on the use of force, with some attention to political economy but more to discourse and narrative concepts. However, private security provision is only a small portion of state-funded security outsourcing, while troubling, is still a relatively small portion of total state-funded military and security activities in the world. Further, the state may have retreated from economic matters (deregulation of global economy, etc.), but it has emerged strongly to address immigration and border issues especially, not to mention foreign military engagements. It is not a simple either-or binary issue (strong state-weak state - it can be both depending on the issue, but is nearly always subservient to capital). The authors provide us with an original context in which to locate violence, regarding armed conflict and war (as social experiences), where violent experiences and traumatic events shape social action by work embedded in cultural coding. 
Boyce and Miller explore the expansive nature of post 9/11 US border expansion, focusing on the US-Canada divide, and the increase in racial-ethnic profiling of Latinos, even in a region where there are relatively few, by the Border Patrol, illustrating its character as a national quasi-racial-ethnic police force. Over the past 20 years, the US has undertaken an unprecedented build-up of its enforcement capacity along the country's border with Canada. Officially, this enforcement build-up is justified with reference to the specter of terrorism and the kinds of security concerns that proliferated in the aftermath of the terror attacks of September 11, 2001. Although along the US/Mexico border agents arrest many more individuals actively seeking to enter the US, here too apprehension records reveal the arrest of hundreds of US citizens and thousands of individuals who are long-term US residents, through the very same kinds of practices - transit checks, roving patrol stops, highway checkpoints and third-party law enforcement custody-transfer - observed above in urban and rural areas across the southern US borderlands.

Sümer explores theoretically the invisible dimension of violence that goes in counterinsurgency operations, analyzing the cultural rationality and physiological effects arising from the use of dead bodies and human remains for sending political messages. He examines historical records as well as the everyday culture through the lens that ethnographic and geographic methods provide. Through necropopulism (using Mbebe's critique of Foucaldian bio-power) and the "averted medicolegal gaze," he compares Turkey and Mexico as nation-states whose governments make use of invisible violence through institutionalized mechanisms. By arguing that these mechanisms are created through a regime of counter-forensics and systematic impunity (examples of the political lives of slain insurgents and dead protestors), he defines necropopulism (in the period of resurgence of imperialism) represented as the discursive representation of the border, as a site of legitimate and expected violence: dying migrants as a spectacle of protected borders. He discusses the way in which political control attained through the use of dead bodies also applies to an understanding of the power configurations at the border crossings, where migrants often encounter violence in myriad forms.

Long before Central American migrants reach the US-Mexico border, they travel for weeks or months through some of the most impoverished regions of Mexico, some riding on the roofs of freight trains. It is a difficult journey even for those who make it to the US, because they sometimes face deportation. Each week a steady stream of migrants is arrested and deported from the US to El Salvador, Guatemala and Honduras, the Northern Triangle of Central America. In the last decade there has been an increase in the number of Central American migrant deportations; after the Mexicans, Northern Triangle emigrants are the most numerous. Rosales Sandoval examines how migrant-sending states are institutionalizing reception policies for deported migrants. These policies vary from country to country and can include the creation of institutions, programmes or statistical databases, or short-term actions such as providing snacks, phone calls and currency exchange to deported citizens. She asks which factors make some sending states reluctant to implement reception policies and argue that since deported migrants represent neither a political nor an economic gain, governments give limited attention to reception policies.

In the revival area of border studies of a Latin American tripartite border, Iturra Valenzuela focuses on Chile's extreme northern region, where borders have historically been highlighted by the migratory circularity between inhabitants of the surrounding countries. However, the current Colombian, Haitian and Venezuelan migration flow has caught the attention of social scientists and politicians. He details the 2018 Plan Frontera Segura. This 
logic of selection of trade and migration flows, between what is desired and the unwanted, is framed in the Foucauldian terms of a neoliberal governmentality and more precisely in an exercise of biopolitics where there is one desired migratory population and another unwanted. He underlines how the Tacna-Arica urban complex operates as an integration space but necessarily produces an asymmetry allowing, on the one hand, the exploitation of Peruvian migrants who insert themselves to work in the agricultural world of Arica, and, on the other, making public the discourses of President Piñera highlighting bilateral trade relations and promoting humanitarian aid for countries in conflict, but in turn denying the entry of poor Venezuelans in order to protect the border.

\subsection{Part III: Challenging Mediterranean Borders}

Part III on Mediterranean borders starts with the history of migration marked by periods of racism and violent rejection and also by periods of peaceful integration and assimilation in immigration countries. Palidda opens such a narrative with the understanding of the consequences of the economic neoliberal global "revolution," which have generated today's migrations in the transition from a more tolerant biopolitics of migrations favorable to the migrant integration into the receiving society to a more coercive thanatopolitics of death and exclusion. This is basically the radical shift in the meaning of migration policies: from let live to let die, especially in the Mediterranean. Therefore, migration and borders shift and the migrants become "wasted lives" or get trapped as "excess humanity." For Palidda, Pandemics are also part of the understanding of the migration paradigm and borders. Among the first measures adopted by nearly all governments in the Covid-19 crisis was the closure of borders (or large-scale restriction of migration), the abandonment of any duty to help refugees, which has resulted in the tragic aggravation of the situation of migrants located near borders, exemplified especially on the Turkish-Greek border zone.

Solidarity movements have had a particularly relevant role in the post-2011 period, which has been characterized by relevant changes in the Mediterranean space, both concerning migration routes and border management strategies. Denaro shows it particularly in the frame of Syrian migration to and throughout Europe, observing an increase of communication exchanges among refugees and a wide array of - old and new - listeners of such voices. The context is the insufficiency of the resettlement policies and the absence of humanitarian corridors to Europe that have forced people to challenge the European border regime. Bringing empirical references from the Greek-Turkish border, this chapter aims at analyzing how the individuals and associations performing solidarity with migrants on the move have been represented by the dominant narratives in the media (as key actors in humanitarian practices), and - in some cases - legally prosecuted for smuggling related accusations.

Ribas-Mateos covers a theoretical challenge set on a complex framework, considering the proliferation of spaces concerning the situation of migrants trapped in Libya and the proliferation of borders and actors when dealing with this topic. The research entails an action research (development of human rights) with a gender perspective. This perspective gives the reader a way into a complex understanding about existing extreme violence. Apart from extreme violence many other concepts end up making us reflect on the understanding of suffering, distant suffering (the view from a distance and the outsider view) when considering the answers to humanitarian crisis, as well as the question of humanitarian accountability and the NGOs' advocacy in cases of extreme violence. 
Fernández-Suárez, focusing on the case of Spain, is able to unveil how in Western countries the political agenda on migration management has its main focus on migration control. Her arguments are based on the emergence and growth of xenophobic parties in Europe which have caused a rise in hate speech and this has been followed by "welfare chauvinist" policies and by emotional responses (in opposition to empathic and compassionate policies). In order to analyze the development of her research she also uses as references the context of restrictive liberalism in Western societies, the paradigm of late neoliberalism, populism, and necropolitics.

Navone shows the paradigmatic violent border in the case of Palestine as demonstrating all the elements needed to designate it as a case of "humanity in excess" using Pablo Vila's (2000, 2003) idea of borders reinforcing fractured identities between and among various ethnic communities. It is based on ethnographic materials collected during fieldwork on the borderland between Egypt, Israel, and the Gaza Strip, between 2009 and 2011. The chapter is based on participant observation and on several interviews conducted around the Rafah Border Crossing, on the Egyptian side. During the random and unpredictable openings of the border crossing, thousands of people stand in a queue in front of the terminal, waiting to cross the border. How does this "triangular" border work? When and where does it work? Who is allowed to cross it? Who is not? Can an adequate answer to all these questions be provided by interpreting the border as a membrane, compressed between opposing forces acting from either side - "border crossing" versus "border reinforcing," inside versus outside? What emerges from Navone's research is the widespread perception that the border, balanced unsteadily beneath the pressure of multiple forces, is not functioning. He focuses on the reconfiguration of the border system taken on following the Egyptian revolution. How does it function currently, and what are its effects on Palestinian mobility, and particularly the importance of vast smuggling efforts. The new spatialization of the border has broadened its magnitude, further complicating its identification, the understanding of its functioning, and its crossing as well as the policies directed to population on the move.

In a very little researched area of the Mediterranean borders, Cabezón-Fernández, Sempere-Souvannavong and Mazouni examine the movements of population between Spain and Algeria and the changes in control since the 1990s, when Spain became a member of the European Economic Community. Since then, the visa policy has been an unbreakable boundary for the political class whereas the population from both sides of the Mediterranean claim better conditions. Graphics are also attached to this chapter.

This section ends with a very local and grassroots context through an specific location in Catalonia. Lundsteen, inspired by the ideas of Yuval-Davis, et al. (2017), analyzes the everyday bordering practices in a small town as a paradigm of contemporary politics of belonging in Catalonia, in relation to the Spanish state. Through an approach close to a symbolic-interactionist approach and extensive use of qualitative data of close observations and interviews/conversations, he unveils how the fluid bordering process used by "locals" or white nationals in relation to immigrants is obviously relevant to our topic (immigrants and borders). However, it is more about the border as a metaphor than the geopolitical boundary, by arguing that, although Catalan ideas of belonging might be more open to other sociocultural expressions, they have their limits and inherent dominant ideas of what is more "at home" than others. On the other hand, nonetheless, attempts at constructing an urban belonging or citizenship has the same fate, as they often ignore the underlying socio-spatial inequalities. 


\subsection{Part IV: Regions, Partitions, and Edges}

Sassen gives us a very interesting theoretical reflection on the predatory character of modern global capitalism, and how it has left populations behind, so tremendously shaping migration, and, moreover, it is in danger of extinguishing human life via climate change. Such predatory character includes mining, plantations, land grabs to expand cities or new built types of private enclaves for the rich, water grabs by the big bottlers, and more. These modes of development are typically registered as "economic development" and show up as growth in a country's gross domestic product (GDP). The fact that they expel millions of smallholders and often destroy small manufacturing and other local economic activities is not registered in those measures. The millions who have been expelled from their land (mostly in Africa, Asia, and Latin America) are invisible to these standard measures. The options they typically face are either to go to the slums of big cities in their own countries or try to emigrate. Confronted with this situation, can we develop a new legal regime that recognizes these outcomes and either condemns them or secures justice for the millions of people whose sources of livelihood are being summarily and often brutally destroyed?

In such extreme conditions, Sassen tries to de-stabilize the concept of the border in the context of predatory practices based on expulsions and extractive logics (see, for example, Chapter 20 on the Amazon in the handbook) in different regions of the Global South. This multi-decade history of destructions of rural economies and expulsions dressed in the clothing of "modernization and development" has reached extreme levels today: vast stretches of land and water bodies are now dead due to mining, plantations, and water extraction by the likes of Nestlé. At least some of today's localized wars and conflicts in Africa arise out of such destruction and loss of habitat; climate change further reduces livable ground. And access to Europe is no longer what it used to be. According to Sassen, this mix of conditions - wars, dead land, and expulsions of smallholders from their modest economies in the name of "development" - has produced a vast loss of life options for a growing number of people in more and more communities. We see this in areas as diverse as Africa, Central America, and parts of Asia, notably Myanmar.

Gaynor takes us to Burundi (ranking as one of the poorest countries in the world), situated within the volatile Great Lakes region of Africa, the country has suffered decades of violence, displacement, and re-displacement. As violence and insecurity continues, most notably following a third term bid in 2015 by the country's president, an estimated 400,000-500,000 have been re-displaced, mostly across regional borders into neighboring Tanzania, Rwanda, the Democratic Republic of the Congo, and Uganda. This chapter examines the reasons for this movement. Exploring the complex root causes of violence and instability, it moves beyond simplistic internal ethnic explanations and highlights the role of the global political economy in fomenting and sustaining insecurity, both within the country and on its borders. The chapter goes on to examine regional responses and policies to the ensuing displacement. Noting that the country continues to receive both the lowest level of international funding for refugees and relatively low levels of international aid, it makes the case for a globalized politics of compassion and responsibility in responding to and tackling the globalized root causes of structural violence in this border region. Thus, Gaynor gives an empirical account of the notion of a "globalized politics of responsibility" as key concept for the handbook.

Following on the regional scale focus we focus then on the Amazon, through a very interesting chapter, both conceptually (with a highly complex frame) and empirically. It is composed 
of different types of research conducted by Nieto Olivar, Melo and Tobón in a region divided between Brazil, Peru, Colombia, and Venezuela in the Northwest Amazon. Described within the vertices of a quadrangle of destruction that connects four cities of the Brazilian Amazon: Novo Progresso and Altamira in the state of Pará, and São Gabriel da Cachoeira and Tabatinga in the state of Amazonas. They research managing human (and non-human) insecurity and violence as a form of production, transformation, and governance in one of the most important transborder regions on the planet, in the Amazonian frontier, observed as a plural object being disputed by capitalist extractive forces. The contextual debates are: the Anthropocene and Cosmopolitics, articulating three axes through which the politics of violence, control, production, and destruction gain expression. These small Brazilian cities and the people who inhabit them have had their lives traversed by highly predatory "national defense," "regional development," "social," and "civilizational" policies based on the reckless exploitation of the much coveted Amazonian "natural wealth" and upon the "need" to guarantee national sovereignty. The necropolitical devices upon which this destruction is conducted also mark bodies, especially those of indigenous people, youth, and women, such as the hungry and drunken Hupd'ah bodies scattered in the camps of the "Beiradão," or the abused and abandoned bodies of indigenous girls in downtown São Gabriel da Cachoeira. From the Venezuelan border to the Peruvian-Colombian border, blood and smoke mingle with cocaine and the device of violence as a form of government materializes in militarized bodies that act together, extensively and intensively, on the territories of the upper Rio Solimões combating the "violence" of international drug trafficking with the "violence" of militarized forces.

We move again to the regional focus, this time towards Southeast Asia with the chapter on Macau (by Gomes Dias and Macaísta Malheiros). The focus is on the old colonial Portuguese territory within a historical perspective (from 1999). From its origins in the mid-sixteenth century to the founding of the Macao Special Administrative Region (MSAR) in 1999, the definition of the land and sea boundaries of Macao has always been an issue, assuming a character that can be analyzed in different dimensions. From the diplomatic point of view, the question of the boundaries of Macao remained a matter of dispute. In its political dimension, the option assumed was to maintain the status quo defined in the late nineteenth century as a way of preserving the economic and sociocultural characteristics of the city. At the social level, it has maintained its role as a port of entry and passage for various migratory movements, including not only commuting between Mainland China and Macao, but also the reception of refugees, Portuguese and Chinese, a particularly relevant phenomenon in the twentieth century. The uniqueness of the chapter on the "Macau case," from its historical perspective, makes it possible to understand today's reality, as a region with a special administrative status, preserving border control mechanisms and flexibility of labor mobility in a specific political and economic context, of progressive integration into the People's Republic of China.

Going back to Eastern Europe as an illustration of cases, Uehling explores what has been transpiring at the contested border between the Russian Federation and Ukraine over the disputed territory of Crimea. While it is well known that the Russian Federation annexed the territory in 2014, few know of the civilian blockade, which has been successful in modifying the flows of people, capital, and goods. Indigenous activists opposed to Russian rule stopped the illicit flow of goods, made Russian electricity more expensive to supply, and took on functions of the state in monitoring the human rights of border crossers. The differences that can be observed between this border and more paradigmatic examples trouble current theorizing on border regimes in two principal ways. First, it was indigenous activists, not the authori- 
ties of either state that imposed more rigorous filters. Second, the activists responded with counter-measures that expose the mirrored and performative nature of border security. The chapter contributes to the volume as a whole by vividly describing the lived experience inside the activists' armed compound, demonstrating how border restrictions are not the sole purview of state border and security services, and revealing the micro-solidarities and emotional resilience of people seeking to ameliorate the human rights situation in Crimea.

Next is the collective chapter by Hayward, Leary and Komarova on the Irish border, an empirical topic that is of great importance and likely to reveal much for the future. It shows the challenges of managing the Irish border after Brexit, the UK's decision to leave the EU centered on a campaign to "take back control" of its borders. This objective was largely assumed to mean controls on the movement of people through British sea and airports. The movement of goods and services across the UK's 500 kilometer land border with the EU was given scant consideration. Two and a half years on, it has proven to be the most complicated challenge for the Brexit process - and one that creates an incredibly complex case for future border management. The border that partitions Northern Ireland from the rest of the island of Ireland has been contested since it was drawn (what many expected to be a temporary measure) almost a century ago. While unionists have seen it as a vital means of preserving British culture and rule in Northern Ireland, Irish nationalists detest it as a lingering manifestation of British colonialism. This is a result of two key processes that fundamentally changed the relationship between the UK and Ireland. First, the peace process built on the 1998 Good Friday (Belfast) Agreement and, second, their common membership of the EU. In fact, the benefits of free movement of goods and services through the UK and Ireland's common membership of the EU's customs union and single market really couldn't be properly felt in the Irish border region until the peace process bore fruit. Apart from showing the big macro picture and the historical context in depth the authors also incorporate the micro community level with the Pettigo case study.

\subsection{Part V: Violence and Containment - Approaches to Youth and Gender}

Part V focuses especially on youth and gender, as the title suggests, first with the chapter by Kastner, who examines a harsh reality through a bodily migrant's experience of borders making clear empirically the asymmetrical and dynamic relationship between social structure and human agency, in this case the social structures impacting migrant women and the human agency of vulnerable, highly disadvantaged African undocumented/unauthorized migrants to Europe (the Western route to Spain). She offers us rich tools on border ethnography, where the body plays a crucial and ambivalent role as both an object of violence and a means of protection and capital.

Going South towards Cameroon, Yambene Bomono (also along the thematic line of Rosales Saldoval's chapter) show us how the state basically abdicated its role to care for the safety and well-being of its returning citizens. This is a very important finding when discussing the border implications for Cameroonian return migrants from the Central African Republic (CAR) that had previously been migrants in CAR. The context is long-term violence as, since the 1960s, the history of CAR is marked by political insecurity. Recurrent episodes of violence, banditry, rebellion, and successive overthrow of government can be observed. Today the country is mostly controlled by criminal armed groups struggling among themselves to appropriate the country's resources. This insecurity mainly affects the frontal areas and there- 
fore neighboring countries. With CAR, Cameroon shares a long border of 797 kilometers. It is located in eastern Cameroon and west of CAR. Historical and geographical links unite the two countries. On both sides of the Cameroonian-CAR border, societal composition is almost identical. The two dominant ethnic groups are the Fulani and Gbaya. This means that in this neighboring region, inhabitants share the challenges of security and humanitarian crises due to CAR's troubled history. Because of countless government overthrows, rebellions, and mutinies in CAR, many CAR nationals and Cameroonian citizens have lost their lives and property. The 2013-2014 crisis is a perfect illustration. The March 2013 putsch of Michel Djotodia, supported by the Seleka militia composed mostly of Muslims, first led a population flow to Cameroon composed mostly of Gbaya suspected of being pro-Bozize, the deposed president. The chapter highlights the experiences of Cameroonian migrants during and after the CAR crisis of 2013-2014 with a focus on key actors that participated in the provision of evacuation, return and reintegration assistance and returnees' reintegration experiences in Cameroon. It is a case study to demonstrate how the repeated crises in CAR endanger the lives of many people on the border of this country. Insecurity on the border is a long-term issue and evolves according to the political context. The research demonstrates concrete ways in which migrants have adopted a range of strategies to flee the host country and also that crisis has long-lasting implications for the mental health of migrants. Discrimination, xenophobia, violence, harassment, beatings, as well as horrific scenes of people butchered with cutlasses, rape and torture were reported.

Not much research has covered the situation of minors and borders in Iran. Thanks to the chapter written by Alaedini and Mirzaei we can understand the situation of Afghans between the border and Teheran. The framework of analysis is the policies in Iran related to migration and borders, welfare and inequalities in urban neighborhoods. Of all of Afghanistan's lawless provinces, Nimruz border region is perhaps the rawest and most untamed of all, located in the desert in south-western Afghanistan, cornering up against Iran and Pakistan. The International Organization for Migration has already made various statements regarding how this border is a main gate for unaccompanied children and youth. Furthermore, the compulsory deportation of some Afghans has raised concerns for human and children's rights organizations and Afghan citizens, making new displaced families. How are these children connected with a wider framework of itineraries with families that have been concentrated in particular neighborhoods of Tehran in the recent period? These connections among youngsters between the border and the metropolis are a central issue of analysis in this chapter.

The notion of human agency in migration is vital, in the case of Jiménez, seen as a form of resistance to the international neoliberal economic policies and abusive policies, in her case applied to teenagers from Morocco migrating to Europe. She unveils her research through the context of the compassion industry. The context is a socio-anthropological interpretation on border policies and the process of securitization in southern borders of Europe, on the basis of the analysis of the functioning of border regimes (from the definition of a legal, technological, and ideological framework), constrained by forms of institutional abuse (arrest, reunification, expulsion, denial of rights, criminalization). In sum, Jiménez opens up many key issues on the research of migration and borders: what is the meaning for migrant and child human rights (not solely the treaties, but the broader ideals), the role of government policies, the role of humanitarian NGOs and social service providers, and the growing issue of unaccompanied minor migrants throughout the world? How is autonomy and agency useful in improving their lives, or are their lives just subject to the control of others? 
Finally, Correia closes the handbook with the maps that accompany the 28 chapters which demonstrate the effect of borders on people's daily and ritual life, in their life transitions and travels, in their aspirations for a better life, and in their experience of violence and forms of compassion. They fundamentally show the interactions between migrants and borders (here represented by policies, politics, law enforcement agencies, and society) in different areas of the world and between and in different countries and regions: USA, Canada, Mexico, South America, Europe, North and Central Africa and Asia. The maps created in this book follow a non-traditional format. Still, they are accurate enough for one to easily understand where each chapter takes place. The style used was drawn from the abstract and fragment pieces from geography that are usually in our mind when we think about countries and the world's borders.

\section{CONCLUSION: THE POWER OF PARADOX}

No es la geografía sola la que hace la historia; es el hombre que engendra la historia en la geografía. Jorge Mañach, 1961.

The contribution of the handbook suggests opening at least four different paradoxes which bind several of these chapters together.

\subsection{The Paradox of Contemporary Mobility Itself}

Mobilities are easier and simultaneously harder with emerging nationalism, populism and pandemic measures. In general, according to mobility filters (using long-running ethic and racial profiling), it gets particularly harder for asylum seekers, lower-class migrants and populations from the Global South.

Paradoxes can be reflected in many scales. Territorial subdivisions and geographic borders are essential for understanding phenomena in sociology, political science, geography, history, and economics. They influence the interregional flow of information and cross-border trade and affect the diffusion of innovation and technology. However, the analytical framework for spatially embedded multi-scale interaction is of fundamental consideration.

For our studies, we have selected regions, cities, neighborhoods, communities. Some regions have had a wide coverage, others less. In such an observance of scale we focus on regional patterns of migration, the triple borders (the case of Chile, the case of the Amazon), the colonial powers defining the border (the case of Macau), the Amazon as the configuration of the complex ecological border. Transformation and governance is shown in one of the most important transborder regions on the planet, the Amazon, the huge cosmopolitan frontier.

Such scale makes us also reflect the physicality of the borders: walls, tunnels (the Gaza Tunnel, tunnels for small goods, tunnels for larger goods, etc.), bridges (the international bridges) seas..., the mantling and dismantling of a Tent City (where one sees the clear connection between displacement, disposability and debordering), border and border cities, where port-cities constitute a particular space with specific dynamics within, which contractions driven by globalization appear in a very obvious manner.

Such scale makes us also think about communities, in how the separation between "the same people" is constructed: the cases of Ireland, Cameroon, or different in the case of anti-Latino policing along US borders with both Mexico and Canada or the construction of the foreign neighbour in a small Catalan town. 
Who are the actors of mobilities? In many cases they have been minors and women. For example, with the youngster agency role in the Western Mediterranean, especially in the case of Morocco, the case of the Afghanistan Border to Iranian Cities, with the example in Chapter 26 of teenage children from Afghanistan working in solid ways recycling in Tehran, which follows the tale of large-scale migration traceable over four decades.

Other important actors are also returnees in Latino America and Western Africa. It is shown through the impact of the permanent crisis in the Central African Republic on Cameroonian return migrants. The children are especially selected as being those where the confusions around moral agency is more blatant: poor children, minority children, foreign children, children of immigrants. This is why their situation normally responds to advocacy interests.

Most ethnographic inquires of the handbook are also theoretically laden, mobile and multisided as well as implying complex forms of activism. As shown in Chapter 24, while on a conceptual level, postcolonial and transnational perspectives regarding border zones have contributed to overcoming methodologic nationalism to a remarkable extent, where the impact of borders and boundaries on migrant lives remains formidable.

\subsection{The Paradox of Humanity and the Humanitarian}

Human rights are also additionally precarious at the borders of a State, as this tends to be a space where the State sovereignty and security needs tend to trump civilian and individual rights and liberties - though many of the security concerns in the case of borders between rich and poor nations are largely specious. Humanitarian relief efforts and refugee-support services are also usually based at a border, and these create an entirely different form of cross-border networking and flow of people and goods. Within it, how does civil society organize complex responses? How does the State violate the right of migrants in the midst of pervasive border control and walls construction?

Is violence the paradigmatic concept in this second paradox? Such proliferation of expulsions and violence makes us go beyond the mere description of border violence. However, the real research task is to identify predatory formations which are dressed in pretty robes. The concept of violence (Chapter 2, throw two types of violence, open violence in Mexico, hidden one, in the US through an articulation of physical, mental and structural violence) but often we obscure what is behind violence (Chapters 5 and 18). This is put into context through the role of the US-Mexico border region as a boom region in international capitalism and staging point for contraband in both directions. However, observing violence is an isolated process, one that disrupts the seamless structures and systems of human life without acknowledging its joint causes and effects. There are ways to describe the violence, to replicate, to look for causes but also to obtain their answer through resilience: as with the case of African women on the road to Europe; violence and resilience in border zones. Furthermore, such deepening on violence takes us to another turn, the dispossession of humanity, the emergence of the Arendtian concept of the refugee. In short, many emerging terms that imply that the humanitarian understanding is essential in today's human mobility.

A second concept of this paradox is compassion. Exploring compassion provides insight into how some groups come to be included in circles of concern whilst others remain excluded. Why do good people turn a blind eye to the suffering of strangers? As Chapter 22 indicates, while some analysts argue that compassion is crucial for democratic politics and essential to humanitarian assistance, others are more sceptical, pointing out that compassion has a ten- 
dency to be capricious and often fails to deliver on its promises. Thus, compassion is necessary, but is not sufficient by itself.

Thirdly, the concept to consider is necropolitics. Mourning and death, death in the Mediterranean and horrorism... Necropolitics crosses many chapters of the book, by referring to the works of Mbembe 2003 (see, for example, Chapter 8) as having the sovereign right to kill. Horrorism is then what we find beyond violence, to underline the despersonification of victims, their vulnerability and their condition of being unarmed (see the reference to Cavarero in Chapter 8). We can see it in the case of Mexico, Turkey, Italy...

\subsection{The Paradox of Border Control and Border Policies}

These are expressed at different levels in how borders are applied. For example, by opening the doors to international students and closing them to others.

The first element here is security. Trafficking, militarization, enforcement, technological security, policing, spatial incarceration, confinement, securitization, many names that imply that migrants are invaders and human mobility is an aberration. Overall, the chapters in this volume emphasize just the opposite through the analysis of the diversity of origins, consequences and experiences of varied patterns of human mobility. Through militarization we have the example of the paradigmatic US-Mexico region, put into practice by border law enforcement agencies using all kinds of military equipment, troops, aerial reconnaissance/surveillance. What is more, this connection is even expressed more clearly in pandemic times as a secondary quotation of Chapter 7 mentions: “(...) the real threat to human beings is microbes and being able to control disease is to start controlling your borders".

One can also question what is new in this new security as a global market, like the chapter directed at new security, threat landscape and the emerging market for force. As the humanistic level, the use of force must be regarded as continuum where Foucaldian power is deployed through surveillance and technology in the name of "security and modernity" (Chapter 6), where private actors become today central together with the State security in border zones. Such reflections on security can connect again with drugs and violence as it is exposed through the reflections on the governance of the Amazonian border in contemporary Brazil.

\subsection{The Paradox of Inequality}

Such described inequality in border realities is linked with the discontinuity of geopolitical borders and the porous state: some borders are still weak, others experience a sudden intensified control, others continue the emergence of strict control since the implications of the policies on the "war on terror". How do such contemporary inequalities provoke numerous differentiated forms related to the "encampment of the world", the increase of expulsion, the proliferation of new transitory spaces? What is the impact of such inequalities? Inequalities palpable through human costs of current deportation regimes like in the cases of Guatemala, el Salvador, Cameroon, Central African Republic are the clearest expressions to the punishment to mobility.

What are the answers to them? Probably through global responsibilities which have to be undertaken considering the changes in "migrations and borders" after the "revolution" of globalized economic neoliberalism. From compassion to culpability, the case for a globalized politics of responsibility like in the case of Burundi-Tanzania border are shown in detail. There 
are ways to be found that are far from damaging through human aims, ways that are more equitable and economically sustainable, pathways to global peace and justice

Not only big macro global solutions are to be found, at a smaller scale, others find ways of documenting and denouncing violence at eastern European borders by using the socio-legal relevance of refugee voices through visual research. Last but not least the maps presented at the end of the book do not show the reticular dimensions of human and material movements; they do not show the temporality of circulation; they do not show geo-visualization, nor the "encampment of the world" or changing routes, but they reflect six different figures to think about the cases selected for the monograph. In this way the maps match with empirical analyses of critical border spaces. The book covers extensively the US-Mexico border region and border zones around the Mediterranean. Border issues in South and Central America, Eastern Europe, Northern Europe, the Middle East, Central Africa and South Eastern Asia are also discussed.

\section{NOTES}

1. We would like to thank the publishing team, who have helped us make this dream come true. For proofreading the book we would like also to thank Pamela Londe for linguistic services and the TRANSMENA Project at the UAB for their Scientific Support.

2. Human security is vital to an international migration and gender focus and is a relatively new concept for framing security, as the latter has historically been seen in terms of the nation-state. Ideally, national security promotes the safety and well-being of a nation's citizens, but it excludes immigrants and has often been used to rationalize all manner of repression and coercive policies against civilians to advance state power and elites (Commission on Human Security 2003; Edwards and Ferstman 2010).

3. For instance, neoliberal economic state and multinational corporate policies promote economic austerity and exploitation without benefiting (and often undermining) workers and most others. Meanwhile, military arms sales and interventionist policies by "great powers" are instrumental in much mass violence spurring mass migration (Boulby and Christie 2018).

4. Restrictionist immigration and border policies actually do little to promote security, because they often do not prevent migrants from entering, but only further push them into more risky underground arrangements. Further, migrants generally pose no physical threat (apart from a tiny minority) and immigration generally has positive economic benefits and makes for little competition with native workers (e.g. see NAS 2016).

5. We refer here to human security at borders when the most common way has been to refer to sites of security/insecurity. Many authors, referring to violence and conflict contexts, as expressed by Weizman (2007), use the Israel/Palestine conflict and Israel's conduct as a "laboratory of the extreme." In such an extreme, the site is related to perfecting the politics of fear, separation, seclusion, and visual control; the settlements, checkpoints, walls, and other security measures are also the last gesture in the hardening of enclaves, and the physical and virtual extension of borders in the context of the most recent "war on terror."

6. We have also managed to delineate a reinterpretation of social processes at particular border regions, considering the current dynamics of mobility and its representations in recent decades. In order to do so, the axis of the discussion has been located in the study of common phenomena in both regions of interest: transnational practices; relocation industry through the maquiladoras; the creation of "off-shore" zones; the emergence of transnational mobility; the increased passage of thousands of undocumented workers; the new role of women and border families' strategies; the representations and practices of these spaces; the global meaning of border control; the persistence of the multiple material and digital types of walls; the symbolism of death in border spaces; the social position of minors and their lack of rights - all while taking into account the sociocultural specificities of each region as a whole. 
7. Cartography has offered fertile ground upon which to stress border changes throughout history. Throughout the nineteenth and twentieth centuries scholarly literature gradually made the distinction between boundaries and frontiers clearer by differentiating between a linear and a spatial concept. In the twentieth century, the lexical mismatch between English and Latin languages - as we shall see, 'frontier' always had military connotations - also played a role: where 'frontier' would refer more to a fuzzy border to a zone, in contrast, 'boundary' would refer to the linear legal division and would mostly be set in the context of the restrictive division of nation-states (Ribas-Mateos 2015). Nevertheless, today's tendency is to focus on a more complex understanding of such concepts, but with a special emphasis on the dynamic, interactive, multilayered nature of border relations. Thus, nowadays, we are witnessing a whole new approach to the study of borders and mobilities. We now have literature that covers a range of perspectives from trends in securitization, surveillance to digital borders, biometric borders, materialization of violence at borders, the environment of borders, the externalization of borders (especially by extending maritime boundaries) and the impact of EU enlargement on borders, particularly after the changes witnessed in Eastern Europe during the 1990s. Moreover, between 1989 and 1991, 14,000 km of new international borders were created (Foucher 2007).

8. Logically, a clear contemporary example is that of Syrian refugees. We can see this through the mapping research of Lagarde. He studies the movements of the population of Deir Mqaren a Syrian village between Damascus and the Lebanese border - questioning the reticular dimension of human mobility. Through the life stories of the refugees and the analysis of their migration routes to Jordan and Germany, he deciphers the networks of places and actors often considered marginal, but nevertheless forming the backbone of the roads of exile linking Syria to the rest of the world. Different relational mechanisms allow access to resources (information, mobility, housing, employment) despite the structural constraints migrants continue to face in the mobile, unstable, and particularly labile nature of socio-spatial dynamics (Lagarde 2018).

9. Extreme is often used in humanitarian references or in violence references. Let's consider, for example, the work of war journalists as "in extremis": "It has always seemed to me that what I write is about humanity in extremis, pushed to the unendurable, and that it is important to tell people what really happens in wars" (journalist Marie Colvin in 2001, quoted in Hilsum 2018, p. 4). A second example is extreme violence. In Spring 2019, The MMSH in Paris (see http://www .fmsh.fr/en/research/30040 accessed 25/2/2020), organized a conference on the study of "extreme violence," reflecting on the cooperative approaches and practices of social scientists, humanitarian practitioners, and defenders of human rights in time of war, genocide, and mass crimes. Based on their experiences in Syria, Rwanda, and the Democratic Republic of Congo, they addressed: local determinants of mass killings; relief methodologies and their impacts; the actions of United Nations' multilateral agencies and of international criminal justice and national judicial institutions; and the engagement of human rights organizations. They also covered a collective reflection on the growing challenge of judicialization (recourse to the courts) that creates constraints and dangers for everyone - researchers, humanitarian actors, and human rights defenders - working on the problem of mass crimes. The possibility that they might be obliged to provide access to sources, informants, and testimonies creates situations of legal conflict, testing the professional secrecy by which researchers and practitioners consider themselves to be bound, particularly when such access may endanger witnesses and humanitarian staff members.

10. The use of such extreme violence that we all try to examine is found in many classic authors. For example, in Levi: "I would like to say a word, as an example of extreme violence, at the same time absurd and symbolic, about the use of sacrilege, not by accident but methodologically, of the human body considered as an object, as a thing not belonging to anybody, a thing one can dispose arbitrarily" (Levi 1986: 122, taken from the French version of the Italian book).

11. The concept of the responsibility to protect (R2P) which is assumed as a profound moral imperative in today's world (in the words of Ban-ki-Moon's discourses) has been criticized by some scholars on the grounds that it is incompatible with the principle of sovereignty (Glanville 2016). This implies protecting vulnerable populations from genocide, ethnic cleansing, war crimes and crimes against humanity, even implying military intervention. This idea followed that states had to be accountable to the international society, but at the same time threatens the supposed traditional rights to govern themselves and be free from external interference. At the same time, states have a responsibility to 
protect their own populations from mass atrocities. When referring to the responsibility to protect, in border regions the clash between national sovereignty and human rights of migrants is especially visible (Dunn 2014).

12. "If compassion sets out to change worldly conditions in order to ease human suffering, it will shun the drawn-out wearisome processes of persuasion, negotiation and compromise, which are the processes of law and politics, and lend its voice to the suffering itself, which must claim for swift and direct action with the means of violence" (Arendt 1973: 86-87). "Pity taken as the spring of virtue, has proved to possess a greater capacity for cruelty than cruelty itself", and "politicised pity runs at cross-purposes to the liberal values of respect and tolerance " (idem: 88).

13. These are to be found in the paradoxes of compassion. We somehow touch the difficult emotional complexity of Zweig's novel (Beware of Pity, 2003 [1939]) on the two types of pity, distinguishing the sentimental kind (to fortify oneself against the suffering of another) from the unsentimental but creative kind that is determined to hold out, in patience and forbearance, to the very limit of its strength and even beyond. How do we feel compassion for others when they are considered weaker or less lucky than us? How is compassion a proof of our humanity looked at from the perspective of our relations to individual people or to groups considered as vulnerable? This classic book explores how good intentions do not always involve a positive impact and even the opposite: they can have devastating consequences. To see "the other" through the sentimental feeling, through the desire to protect "the other" from being hurt or to help out at a site of an unacceptable reality sometimes has opposite effects, offering the lies of denial. This is only a very brief comment on the concept of compassion, as we are very aware that there is a much larger and complex debate regarding the ethics of compassion today.

14. See the whole debate in "Ethnography and Theory with Didier Fassin - Conversations with History": https://www.youtube.com/watch? $\mathrm{v}=\mathrm{pNsG5wDWmhw} \mathrm{(retrieved} \mathrm{on} 5$ February 2020).

15. Examples of those conditions of lack of state protection are those of Palestinians living in Iraq in 2003 and Palestinians expelled from Libya in 1995.

16. Child welfare advocates typically take a human rights approach and contend that the children are largely akin to refugees as victims of abuse and economic circumstance. Under this argument, their care and treatment should correspond to the care and treatment of "national" children. Immigration security advocates, on the other hand, argue that unauthorized immigrants (including unaccompanied minors) are associated with increased community violence and illicit activities (such as gang memberships).

17. Even if state and territory continue to play an important role, state territorial power is re-articulated and reterritorialized in relation to both sub- and supra-state scales (Brenner 1998). Here, the nation-state reproduces both old and new roles for administrative forms, including categories and sub-categories of how nation-states classify mobilities and populations. In other words, one can appreciate that border places are configured as a highly complex variety of filtering effects. Such deterritorialization involves a simultaneous reterritorialization process. In order to illustrate this, we shall point to some instances of deterritorialization of border controls, in the sense that controls are now exercised by transportation companies and within the consulates of most countries. As Anderson points out, the controls that were formally concentrated at national border posts are now exercised by a variety of means (Anderson 2000: 25).

18. Sjoberg is making an analogy with medical triage in extreme circumstances, wherein some are "sacrificed" because treating them would take too many limited resources and thus be "inefficient," so that resources can be focused on those deemed more likely to survive with less treatment. Likewise, Sjoberg argues powerful bureaucracies disregard the well-being of the most disadvantaged groups (and at times repress them and/or dissidents advocating for them), because using extensive resources on them would be "inefficient" from the perspective of elites.

19. The US-Mexico border has provided the clearest illustration in sociology and anthropology, the maquiladora export assembly plants concentrated in Mexico's northern border zone.

20. See here other complex notions of this idea of victimhood. As the noted war historian John Keegan said in his recent study of military intelligence, "it is force not fraud or forethought, that counts in modern wars ... the whole point of explaining clean techniques and their history is to demonstrate that there are painful coercive techniques and to alert others to the danger they represent. Until 
recently, most people believed victims of these techniques suffered little or no discomfort" (Rejali 2007: 480).

21. For example in Helena Maleno's case. Maleno's book (2020) portrays a long reflection from the temporality of the 15 months duration of her judicial process (accused by the Spanish police of being a migrant smuggler in Tangiers). In the form of political ethnography she depicts the place of the protagonists on the migration path in the last 20 years, from the construction of the forest city next to Ceuta, the riots against the sub-Saharans in a Tangiers neighborhood, the helplessness of women in trafficking networks to the struggle for the right to life at sea and the lack of recognition of African lives. In all her activist journey she describes the situation of extreme humanity in her situation as a criminalized human rights defender, where a complex debate between the human, humanism, and the limitations of rights erupts. She also addresses persecution, the conception of protection and of suffering, and the understanding of suffering and self-compassion in human rights defenders.

\section{BIBLIOGRAPHY}

Adey, P. (2004) “Surveillance at the Airport: Surveilling Mobility/Mobilising Surveillance.” Environment and Planning A, 36(8): 1365-1380.

Adey, P. (2019) "Evacuated to Death: The Lexicon, Concept, and Practice of Mobility in the Nazi Deportation and Killing Machine". Annals of the American Association of Geographers, DOI: $10.1080 / 24694452.2019 .1633904$.

Agamben, G. (2005) Lo que queda de Auschwitz: El archivo y el testigo. Homo sacer III. Valencia: Pre-textos.

Agier, M. (ed.) (2014) Un Monde de camps. Paris: La Découverte.

Alvarez, R.T. (2012) "Borders and Bridges: Exploring a New Conceptual Architecture for (US-Mexico) Border Studies." Journal of Latin American and Caribbean Anthropology, 17: 24-40.

Anderson, M. (2000) “The Transformation of Border Controls: A European Precedent?" In P. Andreas and T. Snyder (eds), The Wall around the West: State Borders and Immigration Controls in North America and Europe. Lanham, MD, Rowman \& Littlefield Publishers, pp. 15-29.

Arendt, H. (1973) On Revolution. Harmondsworth: Penguin.

Arendt, H. (2006) "Nosotros, los refugiados." In M. Luise Knott (ed.), Tiempos Presentes. Barcelona: Editorial Gedisa.

Berumen, H.F. (2011) “Fronteras imaginadas. Diez notas y una postal.” In N. Ribas-Mateos (ed.), El Río Bravo Mediterráneo. Las Regiones Fronterizas en la época de la Globalización. Barcelona: Edicions Bellaterra, pp. 225-238.

Boltanski, L. (1993) La souffrance à distance. Paris: Métailié.

Boltanski, L. (1999) Distant Suffering: Morality, Media and Politics. New York: Cambridge University Press.

Bornstein, E. and Redfield, P. (eds) (2011) Forces of Compassion: Humanitarianism between Ethics and Politics. Santa Fe, NM: School for Advanced Research Press.

Boulby, M. and Christie, K. (2018) Migration, Refugees, and Human Security in the Mediterranean and MENA. New York: Palgrave Macmillan.

Brenner, N. (1998) "Global Cities, 'Glocal' States: Global City Formation and State Territorial Restructuring in Contemporary Europe.” Review of International Political Economy, 5(1): 1-37.

Commission on Human Security (2003) Human Security Now. New York: Commission on Human Security. https://reliefweb.int/sites/reliefweb.int/files/resources/91BAEEDBA50C6907C1256D19006A9353 -chs-security-may03.pdf (retrieved on 6 June 2020).

Denaro, C. (2016) "The Reconfiguration of Mediterranean Migration Routes after the War in Syria: Narratives on the Egyptian Route to Italy and Beyond." In N. Ribas-Mateos (ed.), Spaces of Refugee Flight: Migration and Mobilities after the Arab Spring in the Eastern Mediterranean. Cheltenham, UK and Northampton, MA, USA: Edward Elgar Publishing, pp. 71-104.

Dinerstein, A. (2015) The Politics of Autonomy in Latin America: The Art of Organising Hope. Basingstoke, UK: Palgrave Macmillan. 
Dunn, T. (1996) The Militarization of the U.S.-Mexico Border, 1978-1992: Low Intensity Conflict Doctrine Comes Home. Austin, TX: CMAS Books, Center for Mexican American Studies, University of Texas at Austin.

Dunn, T. (2001) "Border Militarization via Drug and Immigration Enforcement: Human Rights Implications." Social Justice, 28(2): 7-30.

Dunn, T. (2009) Blockading the Border and Human Rights: The El Paso Operation that Remade Immigration Enforcement. Austin, TX: University of Texas Press.

Dunn, T. (2014) "Immigration Enforcement at the U.S.-Mexico Border: Where Human Rights and Citizenship (\& National Sovereignty) Collide." In C. Mueller and W. Simmons (eds.), Binational Human Rights: The U.S.-Mexico Experience. Philadelphia: University of Pennsylvania Press, pp. 68-87.

Edwards, A. and Ferstman, C. (2010) Human Security and Non-Citizens: Law, Policy and International Affairs. Cambridge: Cambridge University Press.

Fassin, D. (2007) "Humanitarianism as a Politics of Life." Public Culture, 19(3): 499-520.

Fassin, D. (2008) "The Humanitarian Politics of Testimony: Subjectification through Trauma in the Israeli-Palestinian Conflict." Cultural Anthropology, 23: 531-558.

Fassin, D. (2012a) "Humanitarian Reason": A Moral History of the Present. Berkeley: University of California Press.

Fassin, D. (2012b) Moral Anthropology: A Companion. Malden: Wiley-Blackwell.

Fassin, D. and Rechtman, R. (2009) The Empire of Trauma: An Inquiry into the Condition of Victimhood. Princeton, NJ: Princeton University Press.

Fernández-Kelly, M.P. (1983) For We Are Sold, I and My People: Women and Industry in Mexico's Frontier. Albany, NY: State University of New York Press.

Forensic Oceanography (2018) "MARE CLAUSUM Italy and the EU's Undeclared Operation to Stem Migration across the Mediterranean: A Report by Forensic Oceanography (Charles Heller and Lorenzo Pezzani), affiliated to the Forensic Architecture Agency", Goldsmiths, University of London, May.

Foucher, M. (2007) L'obsession des frontières. Paris: Libraire Académique Perrin.

Galván, R. (2014) "Chicana/Latin American Feminist Epistemologies of the Global South (Within and Outside the North): Decolonizing El Conocimiento and Creating Global Alliances." Journal of Latino/ Latin American Studies, 6(2): 135-140.

Glanville, L. (2016) "Sovereignty." In A.J. Bellamy and T. Dunne (eds.), The Oxford Handbook of the Responsibility to Protect. Oxford: Oxford University Press, pp. 151-66.

Graham, D.T. and Poku, N.K. (2000) Migration, Globalisation, and Human Security. New York: Routledge.

Heyman, J. (2017) "Contributions of U.S.-Mexico Border Studies to Social Science Theory." In C. Vélez-Ibáñez and J. Heyman (eds.), The U.S.-Mexico Transborder Region: Cultural Dynamics and Historical Interactions, Tucson: University of Arizona Press, pp. 44-64.

Heyman, J. and Ribas-Mateos, N. (2019) "Borders of Wealth and Poverty: Ideas Stimulated by Comparing the Mediterranean and U.S.-Mexico." In C. Brambilla (ed.), Guest Session on Anthropology and Critical Border Studies. Archivio antropologico mediterraneo 21, no. 2.

Hilsum, L. (2018) In Extremis: The Life and Death of the War Correspondent Marie Colvin. New York: Farrar, Straus and Giroux.

Jiménez, M. (2019) "Externalización fronteriza en el Mediterráneo Occidental: movilidades, violencias y políticas de compasión." https://www.researchgate.net/publication/290212829_Externalizacion fronteriza_en_el_Mediterraneo_Occidental_movilidades_violencias_y_politicas_de_compasion (retrieved on 2 March 2019).

Jones, R. (2016) Violent Borders: Refugees and the Right to Move. New York: Verso.

Lagarde, D. (2016) "Mapping the Encampment of the World and its Consequences on Refugees' Itineraries", paper presented at the Refugees on the Move Conference, CERMigracions, Barcelona, 21-22 April.

Lagarde, D. (2018) "De Damas à Dortmund, le parcours d'une famille syrienne.” In V. Bontemps, C. Makaremi, and S. Mazouz (eds.), Entre accueil et rejet: ce que les villes font aux migrants. Paris: Le passager clandestin.

Levi. P. (1986) Les naufragés et les rescapés. Quarante ans après Auschwitz. Paris: Arcades Gallimard. Translated from Italian by André Maugé. 
Maleno, H. (2020) Mujer de Frontera. Barcelona: Editorial Península.

Marcus, G. (1995) "Ethnography in/of the World System: The Emergence of Multi-Sited Ethnography." Annual Review of Anthropology, 24: 95-117.

Marron, R. (2016) "Introduction. On the Humanitarian Cause." In Humanitarian Rackets and their Moral Hazards: The Case of the Palestinian Refugee Camps in Lebanon. Abingdon and New York: Routledge, pp. 1-29.

Martínez, O.J. (1998) Border People: Life and Society in the U.S.-Mexico Borderlands. Tucson: University of Arizona Press.

Mezzadra, S. and Neilson, B. (2013) Border as Method, or, the Multiplication of Labor. Durham, NC: Duke University Press.

Miller, T. (2019) Empire of Borders: The Expansion of the US Border Around the World. London: Verso.

NAS (National Academies of Sciences, US) (2016) The Economic and Fiscal Consequences of Immigration. Washington: National Academies Press. https://www.nap.edu/download/23550 (retrieved on 1 November 2020).

Oso, L. and Ribas-Mateos, N. (2013) "An Introduction to a Global and Development Perspective: A Focus on Gender, Migration and Transnationalism." In L. Oso and N. Ribas-Mateos (eds.), Gender, Migration and Transnationalism: Global and Development Perspectives. Cheltenham, UK and Northampton, MA, USA: Edward Elgar Publishing, pp. 1-41.

Poguisch, T. (2018) "l Confini Fantasma dell'Europa." In T. Poguisch and T. Milano-Udine (eds.), Decolonizzare le migrazioni. Razzismo, confini, marginalità. Milan: Mimesis/Cartografie Sociale, pp. 41-60.

Purkayastha, B. (2018) "Migration, Migrants, and Human Security.” Current Sociology Monograph, 66(2): 167-191.

Rachik, H. (2012) Le proche et le lointain. Un siècle d'anthropologie au Maroc. Marseille: Parenthèses/ MaisonMéditerranéenne des Sciences de l'Homme.

Rancière, J. (2003) El maestro ignorante. Laertes: Barcelona.

Rejali, D. (2007) Torture and Democracy. Princeton: Princeton University Press.

Ribas-Mateos, N. (2005), The Mediterranean in the Age of Globalization. Migration, Welfare and Borders. New Brunswick: Transaction Publishers.

Ribas-Mateos, N. (ed.) (2011) El Río Bravo Mediterráneo: Las Regiones Fronterizas en la Epoca de la Globalización. Barcelona: Edicións Bellaterra.

Ribas-Mateos, N. (2015) Border Shifts: New Mobilities from Europe and Beyond. Frontiers of Globalization series. Basingstoke: Palgrave Macmillan.

Ribas-Mateos, N. (ed.) (2016) Migration, Mobilities and the Arab Spring. Cheltenham, UK and Northampton, MA, USA: Edward Elgar Publishing

Ribas-Mateos, N. (2019) “Migrants Trapped in Libya: Is Detention and Human Rights' Abuse the 'Solution'”? Seminar, Department of Social and Policy Sciences, University of Bath, March.

Ribas-Mateos, N. (2020) "Borders and Mobilities in the Middle East: Emerging Challenges for Syrian Refugees in 'Bilad Al-Sham'. In Z. Babar (ed.), Mobility and Forced Displacement in the Middle East. London: Hurst and Company, pp. 19-32.

Rossetto, T. (2015) "Performing the Nation between Us: Urban Photographic Sets with Young Migrants." Fennia, 193(2): 165-184.

Sahlins, P. (1990) Boundaries: The Making of France and Spain in the Pyrenees. Berkeley, Los Angeles and Oxford: University of California Press.

Sassen, S. (2014) "Migrants or Expelled? Beyond the 20th Century Migration Modes" (video-conference). Paper presented at the International Conference "Guests and Aliens. Re-configuring New Mobilities After 2011," IFEA Istanbul, 9-10 December.

Sheller, M. and Urry, J. (2006) "The New Mobilities Paradigm.” Environment and Planning A, 38(2): 207-226.

Sjoberg, G. (1999) Bureaucratic Capitalism and Human Rights' Sociology for the Twenty-first Century. Chicago: University of Chicago Press.

Sjoberg, G., Gill, E. and Williams, N. (2001) “A Sociology of Human Rights.” Social Problems, 48(1): 11-47.

Sontag, S. (2003) Regarding the Pain of Others. New York: Picador. 
Ticktin, M. (2011a) Casualties of Care: Immigration and the Politics of Humanitarianism in France. Berkeley: University of California Press; Tucson: University of Arizona Press.

Ticktin, M. (2011b) "The Gendered Human of Humanitarianism: Medicalising and Politicising Sexual Violence." Gender and History, 23(2): 250-65.

Ticktin, M. (2012) Casualties of Care: Immigration and the Politics of Humanitarianism in France. Berkeley, CA: University of California Press.

Uehling, G.L. (2008) “The International Smuggling of Children: Coyotes, Snakeheads and the Politics of Compassion." Anthropological Quarterly, 81(4): 833-872.

UN Human Security Unit (2009) Human Security in Theory and Practice. New York: United Nations. https://www.unocha.org/sites/dms/HSU/Publications\%20and\%20Products/Human\%20Security \%20Tools/Human\%20Security\%20in\%20Theory\%20and\%20Practice\%20English.pdf (retrieved on 1 November 2020).

Velasco Ortiz, L., and Contreras, O.F. (2011) Mexican Voices of the Border Region. Philadelphia, PA: Temple University Press.

Vietti, F. and Scribner, T. (2013) "Human Insecurity: Understanding International Migration from a Human Security Perspective." Journal on Migration and Human Security, 1(1): 17-31.

Vila, P. (2000) Crossing Borders, Reinforcing Borders: Social Categories and Narrative Identities on the US-Mexico Frontier. Austin: University of Texas Press.

Vila, P. (2003) "Conclusion: The Limits of American Border Theory." Ethnography at the Border. Minneapolis and London: University of Minnesota Press, pp. 306-341.

Weizman, E. (2007) Hollow Land: Israel's Architecture of Occupation. London: Verso.

Yuval-Davis, N., Wemyss, G. and Cassidy, K. (2017) "Everyday Bordering, Belonging and the Reorientation of British Immigration Legislation." Sociology, 52(2): 1-17.

Zweig, S. (2003) [1939] Beware of Pity [Ungeduld des Herzens]. London: Pushkin Press. 